\title{
INEEL Air Modeling Protocol
}

C. S. Staley

M. L. Abbott

P. D. Ritter

December 2004

Idaho National Engineering and Environmental Laboratory Bechtel BWXT Idaho, LLC 
INEEL/EXT-04-02511

\title{
INEEL Air Modeling Protocol
}

\author{
C. S. Staley
}

M. L. Abbott

P. D. Ritter

December 2004

\section{Idaho National Engineering and Environmental Laboratory}

Idaho Falls, Idaho 83415

Prepared for the

U.S. Department of Energy

Office of Environmental Management

Under DOE Idaho Operations Office

Contract DE-AC07-99ID13727 


\section{ABSTRACT}

Various laws stemming from the Clean Air Act of 1970 and the Clean Air Act amendments of 1990 require air emissions modeling. Modeling is used to ensure that air emissions from new projects and from modifications to existing facilities do not exceed certain standards. For radionuclides, any new airborne release must be modeled to show that downwind receptors do not receive exposures exceeding the dose limits and to determine the requirements for emissions monitoring. For criteria and toxic pollutants, emissions usually must first exceed threshold values before modeling of downwind concentrations is required.

This document was prepared to provide guidance for performing environmental compliance-driven air modeling of emissions from Idaho National Engineering and Environmental Laboratory facilities. This document assumes that the user has experience in air modeling and dose and risk assessment. It is not intended to be a "cookbook," nor should all recommendations herein be construed as requirements. However, there are certain procedures that are required by law, and these are pointed out. It is also important to understand that air emissions modeling is a constantly evolving process. This document should, therefore, be reviewed periodically and revised as needed.

The document is divided into two parts. Part A is the protocol for radiological assessments, and Part B is for nonradiological assessments.

This document is an update of and supersedes document INEEL/INT-98-00236, Rev. 0, INEEL Air Modeling Protocol. This updated document incorporates changes in some of the rules, procedures, and air modeling codes that have occurred since the protocol was first published in 1998. 


\section{CONTENTS}

\section{$\underline{\text { ABSTRACT }}$ \\ iii}

\section{$\underline{\text { ACRONYMS }}$}

ix

\section{Part A}

\section{Radiological Air Modeling Protocol for Environmental Compliance}

1. NATIONAL EMISSIONS STANDARDS FOR HAZARDOUS AIR POLLUTANTS

A-

$1.1 \quad$ NESHAP Approval to Construct $\quad$ A-

1

$\underline{1.1 .1}$ Emissions Estimates $\quad$ A-

1

1.1.2 $\quad$ Receptor Location $\quad$ A- 
1

1.1.3 Meteorology A-

3

1.1.4 Computer Code A-

3

1.2 NESHAP Monitoring Determination A-

3

1.3 NESHAP Periodic Confirmatory Measurements A-

3

$1.4 \quad$ NESHAP Annual Report $\quad$ A-

4

1.4.1 Facility Emissions Estimating and Reporting A4 
1.4.2 Receptor Locations $\quad$ A4

1.4.3 Meteorology A-

1.4.4 Quality Assurance/Quality Control and Documentation

A-5

2. NATIONAL ENVIRONMENTAL POLICY ACT

6

2.1 Source Terms

6

$2.2 \quad$ Receptors

A-

6

2.3 Summary

A-

6 
3. THE CLEAN AIR ASSESSMENT PACKAGE-1988 CODE A-

8

3.1 Benchmarking the CAP-88 Code A-

8

3.2 Stack Characteristics A-

8

3.3 Radionuclide Considerations

9

3.3.1 $\quad$ Screening Radionuclide Lists $\quad$ A-

9

3.3.2 Treatment of Radionuclide Progeny

A-

10 
10

3.4 Maximally Exposed Individual versus Population versus Worker

A-

11

3.5 Quality Assurance/Quality Control and Documentation Control

A-

13

3.6 Future Modifications

A-

13

4. REFERENCES

A-

14

Part B

Nonradiological Air Modeling Protocol for State of Idaho Regulatory Requirements 
1. INTRODUCTION

4. $\quad$ AIR MODELS

B-

4

$\underline{4} \quad \underline{\text { Screening Models }}$

B-

4

4.2 $\quad$ Refined Models

B-

5. MODEL INPUT

B-

6 
$\underline{5.1}$ Model Options and Switches

6

5.2 Meteorological Data B-

8

$\underline{5.3} \quad \underline{\text { Receptor Data }}$ B-

10

5.4 Model Output and Processing B-

12

6. REFERENCES

14

FIGURES

1. Source grouping (blue circles) by meteorological tower data (GRI, EBR, LOF), and discrete receptors (in red) for INEEL PSD modeling

B-10

2. Example of plots of isopleths from modeled INTEC Main Stack releases, and locations of refined grids (Big Lost River Sinks and Big Southern Butte)

B-13

\section{TABLES}

1. Distances from facilities to nearest INEEL boundary locations within sectors (present MEI locations are shaded)

2. Partial summary of guidance on modeling air emissions for environmental compliance $\quad$ A-7

3. Meteorological data files to be used in CAP-88 for INEEL facilities A-9

4. Parent radionuclides and daughters and corresponding parent decay constant (LAMRR) A-10

5. Variables and input values for CAP-88 PREPAR files for MEI, population, and worker runs A-12

6. Meteorological stations on the INEEL that have model input files $\quad$ B-10 
7. Source locations and minimum ambient air receptor distances for selected INEEL facilities

B-11 


\section{ACRONYMS}

AAC acceptable ambient concentrations

AACC acceptable ambient concentrations for a carcinogen

ACFM actual cubic feet per minute

AG Applied Geosciences (department)

ANL-W Argonne National Laboratory-West

ARA Auxiliary Reactor Area

ATR Advanced Test Reactor

BBWI Bechtel BWXT Idaho, LLC

BPIP Building Profile Input Program

BRC below regulatory concern

CAP-88 Clean Air Act Assessment Package-1988

CFA Central Facilities Area

CFR Code of Federal Regulations

D\&D decontamination and dismantlement

DEQ Idaho Department of Environmental Quality

DOE U.S. Department of Energy

DOE-ID U.S. Department of Energy Idaho Operations Office

EBR-II Experimental Breeder Reactor II

EDF Engineering Design File

EPA U.S. Environmental Protection Agency

ESP Environmental Services Project

GIS Geographical Information System

HEPA high-efficiency particulate air

ICP Idaho Completion Project

IDAPA Idaho Administrative Procedures Act

IDHW Idaho Department of Health and Welfare

INEEL Idaho National Engineering and Environmental Laboratory

INTEC Idaho Nuclear Technology and Engineering Center

IRC INEEL Research Center

ISC Industrial Source Code

JFD joint frequency distribution

LOFT Loss of Fluid Test

MEI maximally exposed individual

MWSF Mixed Waste Storage Facility

NAAQS National Ambient Air Quality Standards

NCRP National Council on Radiation Protection

NEPA National Environmental Policy Act

NESHAP National Emissions Standards for Hazardous Air Pollutants 
NOAA National Oceanic and Atmospheric Administration

NRC U.S. Nuclear Regulatory Commission

NRF Naval Reactors Facility

PBF Power Burst Facility

PC personal computer

PRIME Plume Rise Model Enhancements

PSD prevention of significant deterioration

PTC Permit to Construct

RWMC Radioactive Waste Management Complex

SCFM standard cubic feet per minute

SCRAM Support Center for Regulatory Air Modeling

STAR Stability Array

TAN Test Area North

TAP toxic air pollutant

TRA Test Reactor Area

TSF Technical Support Facility

UTM Universal Transverse Mercator

VD deposition velocity

WRRTF Water Reactor Research Test Facility 


\section{INEEL Air Modeling Protocol}

\section{Part A \\ Radiological Air Modeling Protocol for Environmental Compliance \\ 1.NATIONAL EMISSIONS STANDARDS FOR HAZARDOUS AIR POLLUTANTS}

Title 40, of the Code of Federal Regulations (CFR), Part 61, "National Emissions Standards for Hazardous Air Pollutants" (NESHAP), establishes standards for various radionuclide air emissions sources, including U.S. Department of Energy (DOE) facilities. Subpart H of the NESHAP, "National Emissions Standards for Emissions of Radionuclides Other Than Radon from Department of Energy Facilities," specifies various approval, monitoring, and reporting requirements.

\subsection{NESHAP Approval to Construct}

Any new construction or modification to an existing facility with the potential for radionuclide emissions must be evaluated to determine whether an application for approval under 40 CFR, Section 61.07 is required.

\subsubsection{Emissions Estimates}

Emissions estimates from the proposed project are initially calculated using release fractions and emissions control credits from Appendix D of 40 CFR 61. If the effective dose equivalent to a maximally exposed individual (MEI), calculated using the Clean Air Act Assessment Package-1988 (CAP-88) code, is less than $1 \%$ of the dose standard of $10 \mathrm{mrem} /$ year (i.e., less than $0.1 \mathrm{mrem}$ ), no EPA approval is needed. If the dose exceeds $0.1 \mathrm{mrem} /$ year and EPA approves, a best engineering estimate of the source term, using knowledge of the process and emission control system, can be substituted and the dose recalculated. This recalculated dose is also submitted to the Idaho Department of Environmental Quality (DEQ) for a Permit to Construct (PTC) or for a director's exemption from a PTC.

\subsubsection{Receptor Location}

For calculating doses for Approvals to Construct, the receptor is placed at the maximally exposed location on the Idaho National Engineering and Environmental Laboratory (INEEL) boundary rather than at the MEI location determined for the Annual Radiological NESHAP Report

This is because the latter location has the potential to be different from year to year, whereas a hypothetical, worst-case MEI at the Site boundary will bound any actual location.

The MEI location for this purpose is generally determined by screening calculations using CAP- 88 . Doses are calculated for INEEL boundary locations that are closest within each of 16 compass direction sectors (Table 1). Generally, for facilities on the southern end of the INEEL, the MEI is within the south-southwest sector (CAP-88 sector 8). This is because the predominant nocturnal air movement is 


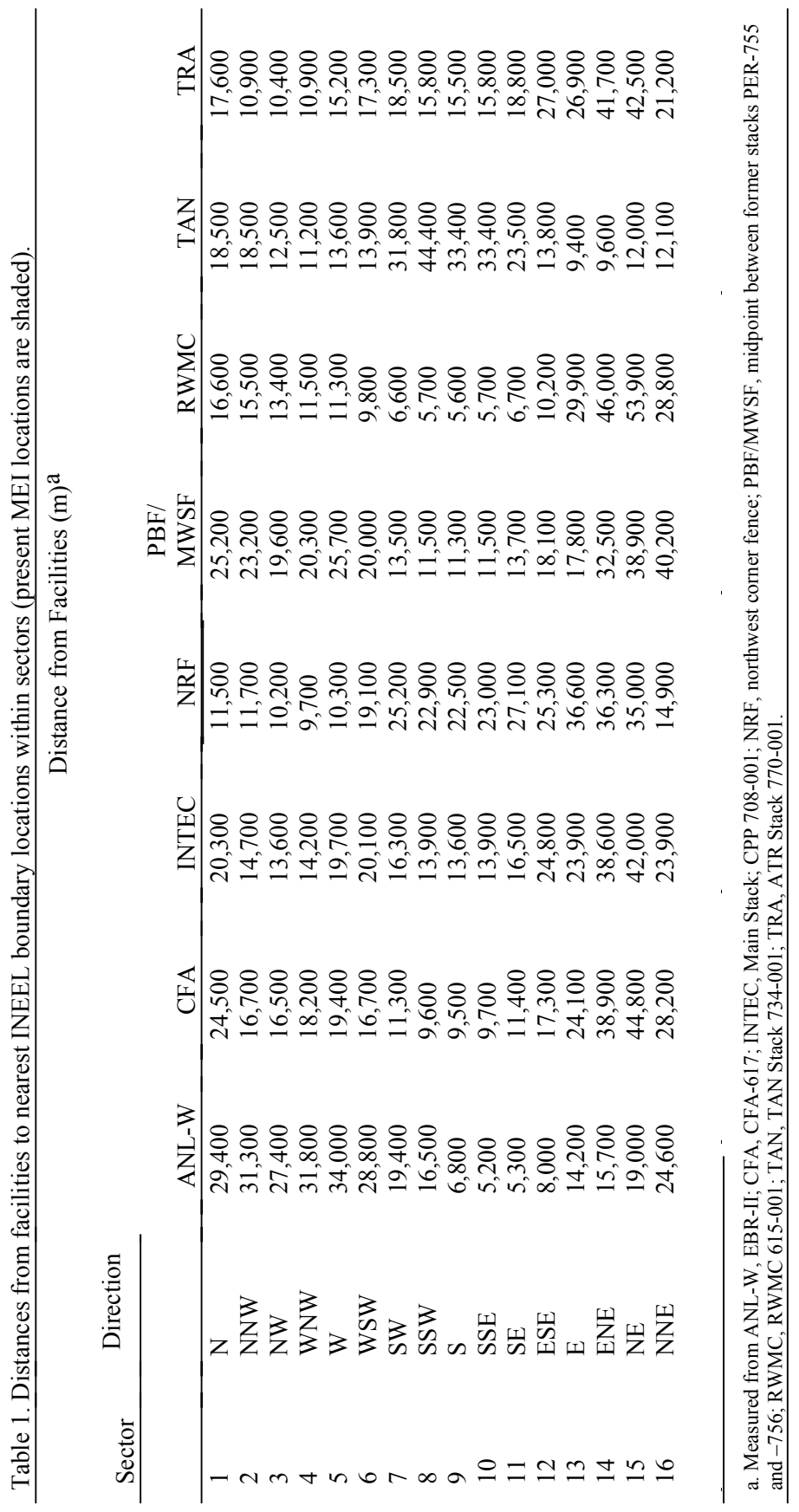


from the north-northeast and these facilities are much closer to the southern INEEL boundary than to the northern boundaries. The Naval Reactors Facility (NRF) is far enough north that the MEI location is to the north of the facility. For the Test Area North (TAN) facility, the MEI location is usually in the northeast sector (CAP-88 sector 15). MEI locations for INEEL facilities are shown as shaded cells in Table 1. Because atmospheric conditions, and, therefore, MEI locations do not tend to change over the long term, only periodic confirmation (i.e., screening runs) of Site boundary MEI locations is necessary.

\subsubsection{Meteorology}

For purposes of NESHAP Approval to Construct and PTC determinations and applications, multiple-year average meteorology should be used. The Applied Geosciences (AG) Department has compiled the last 10 years of annual files (1994-2003) from the National Oceanic and Atmospheric Administration (NOAA) into 10-year-average files for most INEEL facilities. Note that for the Radioactive Waste Management Complex (RWMC), the Central Facilities Area (CFA) 10-year wind file is to be used because problems with the RWMC station rendered some of the 10-year data for that station invalid. The NOAA-provided 10-year average (1994-2003) annual rainfall (CAP-88 variable RR) is 19.4 $\mathrm{cm}$ and temperature (CAP- 88 variable TA) is $279 \mathrm{~K}\left(6^{\circ} \mathrm{C}\right)$.

\subsubsection{Computer Code}

The CAP-88 code is the computer code approved by the U.S. Environmental Protection Agency (EPA) for modeling radionuclide emissions to demonstrate compliance with the NESHAP. There are two versions of CAP-88 that can be used for this purpose: CAP-88 PC, which is a personal computer (PC)-based program, and CAP-88 mainframe, which is a program compiled from a FORTRAN source code. The mainframe version currently is compiled for execution on a workstation cluster (Squadron), which operates under Linux. CAP-88 mainframe is used by the Bechtel BWXT Idaho, LLC (BBWI) AG Department for most purposes, including the NESHAP Annual Report for the INEEL. The CAP-88 mainframe and $\mathrm{PC}$ codes give identical results, but the mainframe version has some advantages over the PC version, especially when programming large numbers of runs. More on the CAP- 88 code is included in Section 3.

\subsection{NESHAP Monitoring Determination}

To determine whether continuous monitoring is required for a radionuclide emissions source, source term estimation and modeling are conducted the same as for NESHAP permitting, except that releases are calculated as if no pollution control devices were in place. Estimated doses exceeding 0.1 mrem at the MEI location under these conditions would trigger the requirement for continuous monitoring of the source in accordance with 40 CFR Part 61.93 (b) (2).

\subsection{NESHAP Periodic Confirmatory Measurements}

Periodic confirmatory measurements are required to confirm that those radionuclide emission sources not requiring monitoring are still below the threshold requiring monitoring, i.e., the dose from

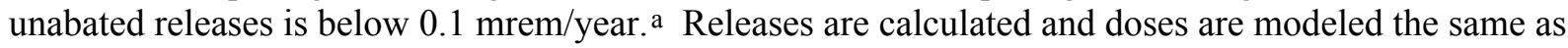
for NESHAP monitoring determination.

\subsection{NESHAP Annual Report}

Section 61.94 of the NESHAP requires each DOE site to submit an annual report documenting Part A-15 
compliance with the NESHAP standard of $10 \mathrm{mrem} / \mathrm{year}$ to the MEI, as defined in the standard. At the INEEL, the annual report is prepared by the Environmental Services Project (ESP) and Applied Geosciences (AG) Departments of BBWI. The ESP collects emissions information from each facility, AG models doses and determines the MEI location and dose, and ESP compiles the technical information provided by AG and completes the annual report. AG follows up with Engineering Design Files (EDFs) that document all procedures and assumptions (see Section 1.4.4).

\subsubsection{Facility Emissions Estimating and Reporting}

Annual emissions from INEEL facilities are currently measured in some cases (monitored stacks), and estimated in most cases. Releases from unmonitored sources are most often estimated from process knowledge (i.e., a release of some fraction of radionuclides used in a given process is assumed). Annual releases are presently documented in Engineering Design Files (EDFs) prepared by each facility and reported in Excel ${ }^{\circledR}$ spreadsheets, termed "screening spreadsheets," which are tailored to each facility. The spreadsheets screen entered releases, writing only those individual radionuclide entries that would exceed a dose of 1E-06 mrem to a separate worksheet for modeling. Those below 1E-06 mrem are considered "not significant contributors" to the overall INEEL dose.

The following reporting protocol has been implemented:

1. The facility point of contact at each facility documents methods and results of radionuclide emissions estimates from all facility emissions points in one or more EDFs. Emissions must be characterized or estimated for all point sources such as stacks and vents, and all non-point (diffuse) sources such as contaminated soil and evaporation and percolation ponds. Releases are entered into screening spreadsheets.

2. Emissions estimates from Idaho Completion Project (ICP) sites, including remediation and decontamination and dismantlement (D\&D) activities, are prepared by ICP personnel, and also documented in an EDF and entered in screening spreadsheets.

3. EDFs and screening spreadsheets are completed and sent to the NESHAP Annual Report coordinator (presently, to Harrison Orr, MS 4110; e-mail ORRHR) by February 28 of the year following the reporting year.

\subsubsection{Receptor Locations}

Modeling for the NESHAP Annual Report involves modeling doses from all INEEL release points that are significant contributors to the maximally exposed off-Site residence, business, office, or school. The methodology for determining the MEI is described in Ritter (1997a), and is summarized here. Doses are modeled from each major release point to 63 actual receptor sites around the INEEL (documented in Ritter [1997b]), and the site with the largest total dose is the MEI location for that year. This modeling requires some 300 to 400 individual CAP- 88 runs. Automated methods have been developed by AG to generate the required CAP-88 input files and to review and summarize the output (Ritter 1997a). Since 1995, the MEI location has been Frenchman's Cabin, just beyond the southern border of the INEEL (DOE-ID 1996, 1997).

\subsubsection{Meteorology}

Meteorological data sets for each calendar year are obtained from NOAA. The NOAA collects data from a series of eight stations on the INEEL, which, with the exception of the Idaho Nuclear Technology

Part A-16 
and Engineering Center (INTEC), are located at the facilities. Wind data for INTEC are collected from the Grid III Station, $1.8 \mathrm{~km}$ north-northwest of the INTEC. Wind data provided by NOAA are in the form of Stability Array (STAR) files, which are read directly into CAP-88. Temperature and rainfall data are also collected by NOAA, who provides annual averages for input to the CAP-88 code. Note that for several years, data from the Radioactive Waste Management Complex (RWMC) Station have been unreliable for various reasons. For example, the 1997 data were compromised by construction activities at RWMC. In these cases, wind files from CFA are substituted for RWMC wind files.

\subsubsection{Quality Assurance/Quality Control and Documentation}

Quality assurance and quality control for the CAP-88 code are discussed in Section 3.5. Each year, all technical input to the NESHAP Annual Report is documented in a series of EDFs produced by AG. These EDFs document the following:

- $\quad$ CAP-88 output files for INEEL major sources, MEI location

- $\quad$ CAP-88 PREPAR (input) form files for INEEL major sources

- $\quad$ Receptor locations for INEEL major sources

- $\quad$ CAP-88 PREPAR files for INEEL major sources

- $\quad$ CAP-88 output files for INEEL minor sources, MEI location

- $\quad$ CAP-88 input parameters for INEEL minor sources

- $\quad$ NOAA meteorological data files

- $\quad$ Benchmarking of CAP-88 code (Section 3.1). 


\section{NATIONAL ENVIRONMENTAL POLICY ACT}

Dose assessments for National Environmental Policy Act (NEPA) documents typically use less conservative assumptions than for permitting purposes. Release estimates are developed using best engineering judgment, and more realistic credit is taken for cleanup by high-efficiency particulate air (HEPA) filters and other controls. Doses are generally calculated to workers and the surrounding population, in addition to the MEI.

\subsection{Source Terms}

Because NEPA documents are usually initiated before completion of a project's Title 1 (initial) design, source terms are generally not well characterized. It is often the case that, at this stage, the modelers must also estimate source terms. Given the many types of projects at the INEEL, it is impossible to write a protocol for source term development. Some basic "tools" that can be used include the following:

- Base the source term on existing, similar processes, scaling as necessary. If the exact process has not been determined, use the worst-case process among candidates.

- $\quad$ Use release fractions, if applicable, from DOE (1994).

- If no applicable release fractions are found in DOE (1994), use the more conservative 40 CFR 61, Appendix D, release fractions.

- $\quad$ Use cleanup efficiencies as provided by the manufacturer for non-HEPA control equipment.

- Use HEPA-filter efficiencies of $99.97 \%$ for the first HEPA filter and $99.9 \%$ for the second, if present.

\subsection{Receptors}

For NEPA, radiological doses to three receptor groups are usually assessed:

- The population within $80 \mathrm{~km}$ of the facility

- $\quad$ The MEI at the Site boundary

- A worker $100 \mathrm{~m}$ from the emission point (100 $\mathrm{m}$ is used because it is the lower distance limit for dispersion calculations).

Population files are constructed as needed by INEEL's Geographic Information System specialists.

\subsection{Summary}

Table 2 summarizes the major guidance on source term calculation, emissions control credit, meteorology, and receptor locations provided in Sections 1 and 2.

Table 2. Partial summary of guidance on modeling air emissions for environmental compliance.

Part A-18 


\begin{tabular}{|c|c|c|c|c|}
\hline Purpose & $\begin{array}{l}\text { Source Term } \\
\text { Calculation }\end{array}$ & $\begin{array}{c}\text { Emission Controls } \\
\text { Credit }\end{array}$ & Meteorology & Receptor \\
\hline $\begin{array}{l}\text { Determine need } \\
\text { for NESHAP } \\
\text { Application to } \\
\text { Construct }\end{array}$ & $\begin{array}{l}\text { Release fractions } \\
\text { from } 40 \text { CFR } 61 \text {, } \\
\text { Appendix D }\end{array}$ & $\begin{array}{l}\text { Cleanup } \\
\text { efficiencies from } \\
40 \text { CFR 61, } \\
\text { Appendix D }\end{array}$ & $\begin{array}{l}\text { 10-year average } \\
\text { Met data or } \\
\text { longest term } \\
\text { average available }\end{array}$ & $\begin{array}{l}\text { MEI at Site } \\
\text { boundary }\end{array}$ \\
\hline $\begin{array}{l}\text { Idaho Department } \\
\text { of Environmental } \\
\text { Quality (DEQ) } \\
\text { Permit to } \\
\text { Construct (PTC) } \\
\text { and NESHAP } \\
\text { Application to } \\
\text { Construct }\end{array}$ & $\begin{array}{l}\text { Best engineering } \\
\text { estimate }^{\mathrm{a}}\end{array}$ & $\begin{array}{l}\text { Best engineering } \\
\text { estimate }^{a}\end{array}$ & $\begin{array}{l}\text { 10-year average } \\
\text { Met data or } \\
\text { longest term } \\
\text { average available }\end{array}$ & $\begin{array}{l}\text { MEI at Site } \\
\text { boundary }\end{array}$ \\
\hline $\begin{array}{l}\text { NESHAP } \\
\text { monitoring } \\
\text { determination }\end{array}$ & $\begin{array}{l}\text { Release fractions } \\
\text { from } 40 \text { CFR } 61 \text {, } \\
\text { Appendix D, or } \\
\text { best engineering } \\
\text { estimate a }\end{array}$ & $\begin{array}{l}\text { No credit for } \\
\text { controls }\end{array}$ & $\begin{array}{l}\text { 10-year average } \\
\text { Met data or } \\
\text { longest term } \\
\text { average available }\end{array}$ & $\begin{array}{l}\text { MEI at Site } \\
\text { boundary }\end{array}$ \\
\hline $\begin{array}{l}\text { NESHAP periodic } \\
\text { confirmatory } \\
\text { measurements }\end{array}$ & $\begin{array}{l}\text { Release fractions } \\
\text { from } 40 \text { CFR } 61 \text {, } \\
\text { Appendix D, or } \\
\text { best engineering } \\
\text { estimatea }\end{array}$ & $\begin{array}{l}\text { No credit for } \\
\text { controls }\end{array}$ & $\begin{array}{l}10 \text {-year average } \\
\text { Met data or } \\
\text { longest term } \\
\text { average available }\end{array}$ & $\begin{array}{l}\text { MEI at Site } \\
\text { boundary }\end{array}$ \\
\hline $\begin{array}{l}\text { NESHAP Annual } \\
\text { Report }\end{array}$ & $\begin{array}{l}\text { Monitored or best } \\
\text { engineering } \\
\text { estimate }\end{array}$ & $\begin{array}{l}\text { Actual or best } \\
\text { engineering } \\
\text { estimate, if } \\
\text { appropriate, to } \\
\text { determine actual } \\
\text { release }\end{array}$ & $\begin{array}{l}\text { 1-year average } \\
\text { Met data from } \\
\text { report year }\end{array}$ & $\begin{array}{l}\text { INEEL Site-wide } \\
\text { MEI, determined } \\
\text { annually }\end{array}$ \\
\hline NEPA & $\begin{array}{l}\text { Best engineering } \\
\text { estimate }\end{array}$ & $\begin{array}{l}\text { HEPA filters at } \\
99.97 \% \text { and } \\
99.9 \% \text {; other } \\
\text { cleanup } \\
\text { efficiencies in } \\
\text { accordance with } \\
\text { manufacturers' } \\
\text { specifications }\end{array}$ & $\begin{array}{l}10 \text {-year average } \\
\text { Met data or } \\
\text { longest term } \\
\text { average available }\end{array}$ & $\begin{array}{l}\text { MEI at Site } \\
\text { boundary, worker } \\
\text { at } 100 \mathrm{~m} \text {, } \\
\text { population within } \\
80 \mathrm{~km}\end{array}$ \\
\hline
\end{tabular}

Part A-19 


\section{THE CLEAN AIR ASSESSMENT PACKAGE-1988 CODE}

The CAP- 88 code is approved by the EPA for NESHAP analyses and has been used for several years by AG to conduct dose assessments. Through most of the $1990 \mathrm{~s}$, some input parameters were modified in an attempt to improve the accuracy of the model or to maximize the dose estimates for conservatism. It was recognized that the radionuclide-specific default parameters within the code have regulatory acceptance, and that use of default parameters facilitates data entry and review of input/output files. Therefore, other than release rates, most radionuclide-specific variables currently are allowed to default.

\subsection{Benchmarking the CAP-88 Code}

The mainframe version of CAP-88 currently resides on the workstation Squadron, which uses the Linux operating system. The code is benchmarked annually against an EPA benchmark case to confirm that the code is executing correctly. This involves running the CAP-88 test case (presented in Beres 1990) provided by EPA and comparing the output to the benchmark case output. In addition, selected CAP- 88 mainframe calculations may be duplicated using the CAP-88 PC code to verify the calculations.

\subsection{Stack Characteristics}

Stack-specific release elevation and flow parameters are used to model dispersion of releases from stacks exceeding 2.5 times the associated building height. This stack: building height ratio is termed "good engineering practice" for stack design (EPA 1995a) and is used in the National Council on Radiation Protection's (NCRP's) method for screening calculations to determine compliance with environmental standards (NCRP 1989). If available, meteorological data collected from the upper level of the NOAA meteorological towers are used to model dispersion from these stacks. The measurement level is entered in the PREPAR file as parameter "Z", although this parameter is not used by the code.

Meteorological data files and $Z$ values are shown in Table 3. All emissions from stacks less than 2.5 times the associated building height are modeled as ground-level releases.

Table 3. Meteorological data files to be used in CAP- 88 for INEEL facilities

Facility Single-Year (yr) Average Wind Files $\quad 10-Y$ ear Average Wind Files “Z” for

Elevated

Releases $^{\mathrm{a}}$

\begin{tabular}{|c|c|c|c|c|c|}
\hline & Ground Level & Elevated & Ground Level & Elevated & \\
\hline ANL-W & EBRL(yr).STR & EBRU(yr).STR & EBRLO.STR & EBRHI.STR & 80 \\
\hline CFA & 690L(yr).STR & & CFA.STR & & \\
\hline INTEC & GRIL(yr).STR & GRIU(yr).STR & GRDLO.STR & GRDHI.STR & 61 \\
\hline IRC & IDA(yr).STR & & Not Available & & \\
\hline PBF & PBFL(yr).STR & & PBF.STR & & \\
\hline RWMC & RWML(yr).STR ${ }^{b}$ & & CFA.STR ${ }^{b}$ & & \\
\hline TAN & LOFL(yr).STR & LOFU(yr).STR & LOFLO.STR & LOFHI.STR & 45 \\
\hline TRA & TRAL(96).STR & & TRA.STR & & \\
\hline
\end{tabular}

Part A-20 
a. $\mathrm{Z}$ for all ground-level measurements is $10 \mathrm{~m}$ for data from the lower level of a two-level tower, and $15 \mathrm{~m}$ from all other towers. CAP-88 mainframe and PC versions apparently do not adjust for measurement height. Input for $\mathrm{Z}$ is provided to document measurement level.

b. Wind data from RWMC for 1997 and therefore for the 1994-2003 long-term average are considered unreliable. For these periods, the CFA wind data are substituted.

\subsection{Radionuclide Considerations}

\subsubsection{Screening Radionuclide Lists}

Often, source terms provided to AG include long lists of radionuclides, many of which have negligible dose consequences. A screening method has been developed and used by AG (Abbott 1994) to screen out such inconsequential radionuclides. The method uses National Council on Radiation Protection (NCRP) air screening factors (NCRP 1996) in a spreadsheet as follows:

1. The calculated release of each nuclide is multiplied by the nuclide's screening factor (in units of dose per unit air concentration) to give a relative risk.

2. Nuclides are sorted from greatest risk to least risk.

3. Relative risks for all nuclides are summed to give total risk.

4. Percentage total risk is calculated for each nuclide.

5. Cumulative percentage risk is calculated, and the radionuclides, which account for $99 \%$ of the total risk from all nuclides, are used for dose modeling.

It should be noted that this screening methodology cannot be used for NESHAP reporting of radionuclide releases, but is useful for permitting and monitoring determinations and for NEPA dose assessments.

\subsubsection{Treatment of Radionuclide Progeny}

Certain radionuclides have daughters that are not always specified by those supplying source terms, but which may contribute significantly to the total parent: daughter dose. The most commonly encountered pairs at the INEEL are Cs-137/Ba-137m, Sr-90/Y-90, Sb-125/Te-125m, and Ru-106/Rh-106. In these pairs, the parents have much greater half-lives than the daughters. For modeling purposes, therefore, the pairs are assumed to be in secular equilibrium. In the pair Pu-241/Am-241, the daughter is much longer lived than the parent. In this case, we assume as a starting point a peak activity for Am-241, which is about $0.033 \mathrm{Ci}$ per $\mathrm{Ci} \mathrm{Pu}-241$.

Three other relatively common radionuclides decay to multiple daughters in a chain. These are Th-232, U-233, and U-238. Th-232 decays to Ra-228, Ac-228, Th-228, and Ra-224. The chain continues, but these four daughters account for $97 \%$ of the dose from daughters of Th-232, and Th-228 accounts for $91 \%$ of the dose from these four daughters. U-233 decays to Th-229, Ra-225, Ac-225, and so on. However, only Th-229 has any dose consequence, accounting for only up to about $2.5 \%$ of the total dose from parent/daughter. U-238 decays to Th-234, Pa-234m, and Pa-234. However, the daughters contribute less than $1 \%$ of the total dose from parent/progeny and can usually be ignored in dose modeling.

Initial curie release quantities for daughters in these parent/daughter sets are entered according to 
Table 4. The variable "IAN" is entered following the release rate as $-1,-2$, etc., for successive daughters; this variable refers back to the radiological decay constant of the parent radionuclide to account for decay during atmospheric transport. The radiological decay constant for the parent radionuclide (LAMRR, Table 4) is entered for each daughter under "MODIFICATIONS OF NUCLIDE DATA" in the PREPAR file to account for radioactive decay after deposition.

Table 4. Parent radionuclides and daughters and corresponding parent decay constant (LAMRR)

\begin{tabular}{|c|c|c|c|c|c|}
\hline $\begin{array}{c}\text { Parent/ } \\
\text { Progeny }\end{array}$ & $\begin{array}{l}\text { Ci Progeny/ } \\
\text { Ci Parent }\end{array}$ & $\begin{array}{c}\text { LAMRR } \\
\left(\mathrm{d}^{-1}\right)\end{array}$ & $\begin{array}{l}\text { Parent/ } \\
\text { Progeny }\end{array}$ & $\begin{array}{c}\text { Ci Progeny/ } \\
\text { Ci Parent }\end{array}$ & $\begin{array}{c}\text { LAMRR } \\
\left(\mathrm{d}^{-1}\right)\end{array}$ \\
\hline Sr-90 & & & $\mathrm{Pu}-241$ & & \\
\hline Y-90 & 1.0 & $6.64 \mathrm{E}-05$ & Am-241 & 0.033 & $1.35 \mathrm{E}-04$ \\
\hline $\mathrm{Ru}-106$ & & & Th-232 & & \\
\hline Rh-106 & 1.0 & $1.88 \mathrm{E}-03$ & $\mathrm{Ra}-228$ & 0.91 & $1.35 \mathrm{E}-13$ \\
\hline $\mathrm{Sb}-125$ & & & Th-228 & 0.87 & $1.35 \mathrm{E}-13$ \\
\hline Te-125m & 0.25 & $6.85 \mathrm{E}-04$ & Ra-224 & 0.87 & $1.35 \mathrm{E}-13$ \\
\hline Cs-137 & & & U-233 & & \\
\hline Ba-137m & 0.95 & $6.29 \mathrm{E}-05$ & Th-229 & 0.0019 & $1.19 \mathrm{E}-08$ \\
\hline
\end{tabular}

\subsection{3 lodine-129 from the Idaho Chemical Processing Plant}

Iodine-129 can exist in several forms, with the organic and elemental forms predominating in INEEL emissions. These two forms behave differently when released to the atmosphere and, therefore, have different dose consequences. CAP-88 defaults to elemental I-129, the worst-case form. If the composition of I-129 is known, one should divide the total I-129 source term into separate entries in the PREPAR file, and specify deposition velocities (VDs) for each form. For example, McManus et al. (1982) demonstrated that the distribution of I-129 in fuel reprocessing (specifically, for fuel dissolution) is approximately $36 \%$ elemental and $64 \%$ organic. The VD for organic I- 129 is entered as $1.8 \mathrm{E}-04$. For elemental I-129, no entry is necessary and the code defaults to a VD of $3.5 \mathrm{E}-02$.

\subsection{Maximally Exposed Individual versus Population versus Worker}

The input files specifying radionuclides and release rates, receptor distances and directions, stack parameters, food supply fractions, and other CAP-88 variables are known as "PREPAR" files. MEI, population, and worker dose calculations require different entries for several variables in the PREPAR file. These are summarized in Table 5. Worker calculations are similar to those for MEIs, but the output is adjusted as follows:

- Ingestion dose is subtracted from the total because workers do not consume food grown in the assessment area.

- $\quad$ External dose is scaled by a factor of 2,000 hours/8,766 hours, representing the fraction of the year a worker would be on-Site.

- Inhalation dose is scaled by a factor of 2,400/8,030, representing the reduced amount of inhaled air. This fraction takes into account both the fraction of the year a worker is on-Site, and the higher breathing rate of the worker.

One other adjustment to the PREPAR file for population runs is necessary to assign the agricultural

Part A-22 
and population data files. The following lines of code must be entered after the "AG DATA" entries and before the "USAGE" entries:

\section{AG ARRAYS}

FILE 23

FREE

POPULATION ARRAY

FILE 24

SKIP 2

FREE

Table 5. Variables and input values for CAP-88 PREPAR files for MEI, population, and worker runs.

\begin{tabular}{|c|c|c|c|c|}
\hline Variable & Explanation & & Value & \\
\hline & & MEI & Population & Worker \\
\hline LIPO & Switch for population/individual run & 0 & 1 & 0 \\
\hline NOL & Lower grid limit, direction & Sector of MEI & 1 & 1 \\
\hline NOU & Upper grid limit, direction & Sector of MEI & 16 & $16^{\mathrm{a}}$ \\
\hline NRL & Lower grid limit, distance & 1 & 1 & 1 \\
\hline NRU & Upper grid limit, distance & 1 & 5 & 1 \\
\hline IDIST & Distance from source to receptor $(\mathrm{m})$ & Distance to MEI & $\begin{array}{l}\text { No entry, accounted } \\
\text { for by NRL and NRU }\end{array}$ & 100 \\
\hline TSUBH3 & $\begin{array}{l}\text { Time delay (hours), ingestion of } \\
\text { leafy vegetables by human }\end{array}$ & 336 (default) & 336 (default) & $\mathrm{NA}^{\mathrm{b}}$ \\
\hline TSUBH4 & $\begin{array}{l}\text { Time delay (hours), ingestion of } \\
\text { produce by human }\end{array}$ & 336 (default) & 336 (default) & $\mathrm{NA}^{\mathrm{b}}$ \\
\hline YSUBV1 & $\begin{array}{l}\text { Agricultural productivity }\left(\mathrm{kg} / \mathrm{m}^{2}\right) \text {, } \\
\text { grass-cow-milk pathway }\end{array}$ & 0.28 (default) & 0.7 & $\mathrm{NA}^{\mathrm{b}}$ \\
\hline TSUBF & $\begin{array}{l}\text { Transport time (d), animal } \\
\text { feed-milk-human }\end{array}$ & 2 (default) & 4 & $\mathrm{NA}^{\mathrm{b}}$ \\
\hline FV & $\begin{array}{l}\text { Fraction of vegetables produced at } \\
\text { home, within local assessment area, } \\
\text { and outside assessment area }\end{array}$ & $0.7,0.3,0.0^{\mathrm{c}}$ & $0,0.5,0.5$ & $\mathrm{NA}^{\mathrm{b}}$ \\
\hline FB & $\begin{array}{l}\text { Fraction of meat produced at home, } \\
\text { within local assessment area, and } \\
\text { outside assessment area }\end{array}$ & $0.442,0.558,0.0^{\mathrm{c}}$ & $0,0.5,0.5$ & $\mathrm{NA}^{\mathrm{b}}$ \\
\hline FM & $\begin{array}{l}\text { Fraction of milk produced at home, } \\
\text { within local assessment area, and } \\
\text { outside assessment area }\end{array}$ & $0.399,0.601,0.0^{\mathrm{c}}$ & $0,0.5,0.5$ & $\mathrm{NA}^{\mathrm{b}}$ \\
\hline UV & $\begin{array}{l}\text { Rate of ingestion of produce by } \\
\text { human (kg/year) }\end{array}$ & 176 (default) & 176 (default) & $\mathrm{NA}^{\mathrm{b}}$ \\
\hline
\end{tabular}




\begin{tabular}{|c|c|c|c|c|}
\hline UM & $\begin{array}{l}\text { Rate of ingestion of milk by human } \\
\text { (L/year) }\end{array}$ & 112 (default) & 112 (default) & $\mathrm{NA}^{\mathrm{b}}$ \\
\hline UF & $\begin{array}{l}\text { Rate of ingestion of meat by human } \\
(\mathrm{kg} / \text { year) }\end{array}$ & 85 (default) & $94^{\mathrm{d}}$ & $\mathrm{NA}^{\mathrm{b}}$ \\
\hline \multirow[t]{2}{*}{ UL } & $\begin{array}{l}\text { Rate of ingestion of leafy vegetables } \\
\text { by human }(\mathrm{kg} / \mathrm{year})\end{array}$ & 18 (default) & 18 (default) & $\mathrm{NA}^{\mathrm{b}}$ \\
\hline & - & & & \\
\hline \multicolumn{5}{|c|}{ a. For a worker, doses are calculated in 16 compass directions to find the maximum dose. } \\
\hline \multicolumn{5}{|c|}{$\begin{array}{l}\text { b. Not applicable-workers do not eat food grown on-Site. Usually, values are left set as for an MEI run, then ingestion dose is } \\
\text { subtracted from the total dose in the output. }\end{array}$} \\
\hline \multicolumn{5}{|c|}{ c. Source: EPA (1989). } \\
\hline \multicolumn{5}{|c|}{$\begin{array}{l}\text { d. The Rupp diet (Rupp 1980) includes consumption of } 9.5 \mathrm{~kg} / \mathrm{y} \text { of poultry, for a total of } \sim 94 \mathrm{~kg} / \mathrm{y} \text { meat consumption. The } \\
\text { CAP- } 88 \text { default value does not include poultry consumption. }\end{array}$} \\
\hline
\end{tabular}

\subsection{Quality Assurance/Quality Control and Documentation Control}

A variety of measures are taken to ensure that the dose assessments performed using CAP-88 are suitable for use in compliance-related work. These measures include:

- $\quad$ Configuration control of the code and associated data files, including in-use testing

- $\quad$ Review of the code and output

- Review of the EDFs reporting the results of the analysis.

These measures are discussed further in Ritter (1997a).

\subsection{Future Modifications}

Future modifications that should be investigated are:

- $\quad$ Entries for surface roughness (parameter Z0), and

- $\quad$ Food production (agricultural) parameters used in population dose assessments.

The AG Department presently models with $\mathrm{Z}_{0}$ set to $0.01 \mathrm{~m}$, indicating nearly flat terrain, the most conservative case. The INEEL is sufficiently undulating to justify a nonzero entry for $Z_{0}$. An appropriate value for $Z_{0}$ should be used to document the INEEL's best estimate for this parameter, although it is used by neither the CAP-88 mainframe nor PC codes. Food production values used for population runs are default values based on agriculture in the Midwest United States. This results in overestimating the population dose in southeast Idaho, which has a lower agricultural production rate because of climate and because much of the land near INEEL facilities is restricted for agricultural uses. Future modeling support should include refining these production rates. 


\section{REFERENCES}

40 CFR 61, "National Emission Standards for Hazardous Air Pollutants, "Code of Federal Regulations.

Abbott, M. L. (EG\&G Idaho, Inc.), 1994, Source Term Screening Methodology for Atmospheric Releases of Radionuclides, Engineering Design File RWM-94-001.1.

Beres, D. A., 1990, The Clean Air Act Assessment Package-1988 (CAP-88), a Dose and Risk Assessment Methodology for Radionuclide Emissions to Air, Vol. 1.

DOE, 1994, Airborne Release Fractions/Rates and Respirable Fractions for Nonreactor Nuclear Facilities, DOE-HDBK-3010-94, Vols. 1 and 2.

DOE-ID, 1996, 1995 INEL National Emission Standard for Hazardous Air Pollutants - Radionuclides, Annual Report, DOE/ID-10342(95).

DOE-ID, 1997, 1996 INEEL National Emissions Standard for Hazardous Air Pollutants - Radionuclides, Annual Report, DOE/ID-10342(96).

EPA, 1989, Risk Assessments Methodology, Environmental Impact Statement, NESHAPS for Radionuclides, Background Information Document, Vol. I, EPA/520/1-89-005, U.S. Environmental Protection Agency.

EPA, 1995a, Guideline for Determination of Good Engineering Practice Stack Height (Technical Support Document for the Stack Height Regulations) (Revised), PB85-225241, U.S. Environmental Protection Agency.

EPA, 1995b, Guideline for Air Quality Models (Revised), EPA-450/2-78-027R (also 40 CFR, App. W, changed August 9, 1995), U.S. Environmental Protection Agency.

McManus, G. J., et al. (Exxon Nuclear Idaho, Inc.), 1982, Model of I-129 Process Distributions in a Nuclear Fuel Reprocessing Plant, ENICO-1108.

Mitchell, J. R., Lockheed Martin Idaho Technologies Company, Letter to M. Bauer, Idaho Department of Environmental Quality, July 9, 1996, “INEL’s PSD Modeling Protocol,” JRM-235-96.

NCRP, January 1989, Commentary \#3, Screening Techniques for Determining Compliance with Environmental Standards, National Council on Radiation Protection.

NCRP, December 1996, Screening Models for Releases of Radionuclides to Air, Surface Water, and Ground Water, Draft, National Council on Radiation Protection.

NRC, 1977, Calculation of Annual Doses to Man from Routine Releases of Reactor Effluents for the Purpose of Evaluating Compliance with 10 CFR Part 50, Appendix I, Regulatory Guide 1.109, U.S. Nuclear Regulatory Commission.

Ritter, P. D. (Lockheed Martin Idaho Technologies Company), May 1997a, Method for Determining the Dose Caused by INEEL Operations for the 1995 and Later NESHAP Annual Reports, Engineering Design File NES-96-004.1.

Ritter, P. D. (Lockheed Martin Idaho Technologies Company), 1997b, Source-to-Receptor Range and Part A-25 
Bearing to Potential Maximally Exposed Individuals for Use in Determining Compliance with the National Emissions Standards for Hazardous Air Pollutants (NESHAP), Based on the 1995 INEL Boundary Inspection Flight, Engineering Design File NES-95-004.2.

Ritter, P. D. (Lockheed Martin Idaho Technologies Company), 1997c, Benchmark Testing of the CAP-88 Computer Code, Engineering Design File NES-97-004.2.

Rupp, E. M., 1980, “Age Dependent Values of Dietary Intake for Assessing Human Exposures to Environmental Pollutants," Health Physics, August 1980. 


\section{Part B \\ Nonradiological Air Modeling Protocol for State of Idaho Regulatory Requirements 5.INTRODUCTION}

This section provides guidance on methods and input data that will meet the nonradiological pollutant modeling requirements specified by the Idaho Department of Health and Welfare (IDHW) in "Rules for the Control of Air Pollution in Idaho" (IDAPA 58.01.01). The primary pollutants of concern are carbon monoxide $(\mathrm{CO})$, nitrogen dioxide $\left(\mathrm{NO}_{2}\right)$, particulate matter less than $10 \mu \mathrm{m}$ in diameter (PM-10), sulfur dioxide $\left(\mathrm{SO}_{2}\right)$, lead $(\mathrm{Pb})$, and the toxic air pollutants (TAPs) listed in Idaho Administrative Procedures Act (IDAPA) Sections 585 (noncarcinogens) and 586 (carcinogens). Other pollutants listed in air quality criteria (e.g., ozone and fluorides) are generally not assessed using conventional air modeling techniques.

It should be stressed that this modeling protocol is subject to change because it is based on information and procedures in sources that are infrequently but continually updated:

- IDAPA regulations

- Model change bulletins in EPA Support Center for Regulatory Air Models (SCRAM) online Web site

- Modeling procedures in 40 CFR 51, Appendix W, "Guideline on Air Quality Models" (latest update: July 2003)

- $\quad$ DEQ's Air Quality Modeling Guideline (DEQ 2002)

- $\quad$ Unpublished policies or procedures that may be requested by IDHW.

Because of this, it is recommended that this protocol be reviewed periodically and updated if necessary. 


\section{WHEN MODELING IS REQUIRED}

Under IDAPA 58.01.01, air modeling may be required to demonstrate that facility emissions will not result in downwind air concentrations that exceed several air quality criteria. These concentration criteria include the following:

- $\quad$ Significant contributions to ambient air (IDAPA Section 006.)

- $\quad$ Existing ambient air monitoring de minimus concentrations (Section 202.01.c.)

- $\quad$ National Ambient Air Quality Standards (NAAQS) (Section 577)

- $\quad$ Prevention of significant deterioration (PSD) $1 \mu \mathrm{g} / \mathrm{m} 3$ baseline area (Section 579)

- $\quad$ The PSD increments for Class I (e.g., Craters of the Moon) and Class II (e.g., Market Lake National Wildlife Refuge) areas (Section 581)

- The TAP increments - acceptable ambient concentrations (AACs) for noncarcinogens (Section 585) and acceptable ambient concentrations for carcinogens (AACCs) (Section 586). 


\section{GENERAL REQUIREMENTS FOR AIR MODELING ANALYSES}

All modeling analyses that are submitted to IDHW should include the following:

1. A description of the problem, including the sources that are being modeled, the concentration criteria being investigated, and the pollutants and averaging times being assessed

2. A description of the model(s) used, the date and version number of the model(s), and justification for using the models if they are not a "preferred air quality model," as specified in 40 CFR Part 51, Appendix W, "Guideline on Air Quality Models," or in the IDAPA rules

3. A description and justification of all input parameter values used

4. A summary of the modeling methodology

5. A disk copy of the meteorological input data and model input files

6. A map of the modeled area showing receptor grids and concentration isopleths for each pollutant and averaging time assessed

7. A discussion of the qualitative and quantitative results.

Part B-29 


\section{AIR MODELS}

Current versions of the models described below and their user's manuals may be downloaded from the EPA SCRAM Web site (http://www.epa.gov/scram001/). Alternately, commercial versions with graphical user interfaces (e.g., BEE-LINE software, Ashville, North Carolina; Lakes Environmental Software, www.weblakes.com) may be purchased and used if they have incorporated the EPA most recent SCRAM version and have been verified with EPA test problems.

It is critical that any person attempting to run these models for INEEL applications have a good understanding of air pollution meteorology; air dispersion principles; the modeling procedures given in 40 CFR 51, Appendix W, "Guideline on Air Quality Models"; model user's manuals; and basic air dispersion texts (Hanna, Briggs, and Hosker 1982; Turner 1994).

\subsection{Screening Models}

Screening models are simple models that are used as a "first-cut" assessment of the worst-case impacts from a single source. They are used to demonstrate that predicted impacts are less than some criteria to show compliance. Screening models do not require a site-specific meteorological input file, generally require much less time to set-up and run than refined models, and provide conservative predictions of maximum 1-hour time-averaged concentrations. The 1-hour concentrations may then be converted to longer averaging times (for comparison to appropriate time-averaged concentration criteria) by multiplying by persistence factors, which are very rough, conservative estimates of plume meander effects. If the results from the screening model are unacceptable, then a more time-consuming refined modeling analysis is warranted.

The screening model currently accepted by EPA and the State of Idaho is SCREEN3 (version 96043) (EPA 1995a). At the INEEL, SCREEN3 is generally used only for the initial assessment of TAP increments as specified in IDAPA Section 210. For comparison to 24-hour averaged noncarcinogenic AACs, the SCREEN3 results should be multiplied by a persistence factor of 0.4 . For comparison to annual averaged carcinogenic AACCs, the SCREEN3 results should be multiplied by a persistence factor of 0.125 . Previous modeling studies at the INEEL $b$ have shown that screening models will overpredict annual average concentrations by factors of 17 to 43 (depending on the facility location) and maximum 24-hour concentrations by factors of 2.5 to 6 . Because of the conservative input assumptions built into screening models, modeling results should always be described as upper-bound estimates of impact in the modeling report.

Another screening model used occasionally on the INEEL is TSCREEN (Toxics screening), also available from EPA's SCRAM Web site. This model employs both the SCREEN3 and PUFF models, and is designed for puff, or short-term releases. On the INEEL, it has been applied to explosives detonation releases.

\subsection{Refined Models}

Refined models provide a more realistic estimate of predicted maximum impacts but are more complicated and require significantly more input data and time to run. If compliance or permitting exemption can be demonstrated with a screening model, the use of a refined model is usually not warranted. However, refined models are always recommended whenever cumulative impacts from several sources are evaluated or whenever the modeling results might be potentially added to impacts from other sources. In these cases, the use of screening models will grossly overestimate impacts and could result in 
unnecessary operational restrictions.

The Industrial Source Complex - 3 (ISC3) model (version 96113) (EPA 1995b) is the primary model used for refined air quality modeling at the INEEL. The ISC3 model consists of two separate models: the ISCLT3 "long-term" model and the ISCST3 "short-term" model. The ISCLT3 model calculates only long-term (e.g., annual) average impacts while ISCST3 calculates both short-term (hourly) and annual concentrations, depending on the length of the meteorological input file. The primary difference between the two models is the type of meteorological input data used. The ISCLT3 model uses a long-term (e.g., 5 years or more) joint frequency distribution (JFD) formatted in the NOAA "STAR" format. The ISCST3 model uses sequential hourly surface and upper air data, which are both more detailed than the JFD and have a vastly larger amount of data. In almost all cases at the INEEL, the ISCST3 model should be used because:

- $\quad$ Most air quality analyses need to evaluate both hourly and annual average concentrations

- $\quad$ ISCST3 has advanced plume depletion/deposition algorithms

- $\quad$ ISCST3 is the model used and recommended by the State of Idaho.

The ISC-Plume Rise Model Enhancements (ISC-PRIME) model is the most recent upgrade of the ISC model. ISC-PRIME was designed to incorporate two fundamental features associated with building downwash:

- $\quad$ Enhanced plume dispersion coefficients due to the turbulent wake

- $\quad$ Reduced plume rise caused by a combination of the descending streamlines in the lee of the building and the increased entrainment in the wake.

To provide the needed input to ISC-PRIME, the Building Profile Input Program with PRIME (BPIP-PRIME) was developed by EPA to incorporate enhanced downwash analysis data. BPIP- and ISC-PRIME (using the Lakes Environmental Software interface) will be used for modeling concentrations close to buildings, both on the INEEL and at in-town facilities. 


\section{MODEL INPUT}

\subsection{Model Options and Switches}

The following modeling options should be used for INEEL air quality modeling:

\section{SCREEN3}

- $\quad$ Source type: Point for stack/vent releases, Area for diffuse surface emissions (e.g., ponds, landfills, and construction areas).

- $\quad$ Terrain options: Normally evaluated as Flat for INEEL screening runs. Simple Elevated and Complex terrain may need to be evaluated if downwind receptors of interest are significantly elevated above the stack base (unless the stack is modeled as a ground-level release).

- Fumigation: Inversion Break-up should be evaluated if the model results are to be used for short (e.g., 1-hour or 3-hour) averaging times.

- Dispersion Coefficients: Rural for INEEL runs.

- Meteorology: All Stability Classes and Wind Speeds normally evaluated. Default 10-m anemometer height.

- Ambient Temperature: Use the INEEL average, 279 K (Clawson, Start, and Ricks 1989), if the results are to be converted to annual average concentrations. Higher (e.g., summertime) values may need to be evaluated if the results are used for short averaging times.

\section{$\underline{\text { ISC3 }}$}

- Regulatory default job control and dispersion options, which include the following:

-Final plume rise, stack-tip downwash

-Buoyancy-induced dispersion

-Calms processing routine (meteorological file must be properly processed)

- No use of missing data processing routine (if missing data are filled on met file)

-Default wind profile exponents

-Default vertical potential temperature gradients

-Upper-bound values for supersquat buildings

Part B-32 
- No exponential decay for RURAL mode.

- Dispersion Coefficients : Rural for INEEL.

- Plume Depletion: Evaluate for particle runs if particle-size data are available (from measurements or appropriate AP-42 data [EPA 1995c]). Do not use plume depletion if modeling gases or vapors.

- $\quad$ Averaging Times: Use only annual averaging time for off-Site receptors, and use annual and appropriate hourly (depending on the pollutant) averaging times for public highway receptors.

- Terrain Heights: Receptor terrain heights should always be evaluated unless a ground-level release is being modeled. The Universal Transverse Mercator (UTM) coordinates and elevations should be taken from the INEEL Geographical Information System (GIS) database.

\section{Source Data Input}

- Emission Rate: Use pollutant-specific (grams/second) for point sources, grams $/$ second $/$ meter $^{2}$ for area sources.

The rate is determined by approved measurement methods, engineering calculations, or appropriate AP-42 emission factors. Normally, "maximum" (100\% load) emission rates should be modeled for conservatism, although final PSD modeling may use "actual" emission rates if necessary (if a PSD increment is approached or exceeded using maximum emission rates).

The requirements of the PSD regulations apply to new major stationary sources and major modifications. Once a PSD analysis is triggered, all sources including exempt sources are to be assessed. The BBWI Environmental Policy and Permitting Department maintains a PSD source tracking database for all sources that have air permitting determinations from May 1994 to present, including those sources that are below regulatory concern (BRC) or have a Permit To Constr uct (PTC).

For annual averaging time runs, the emission rate should be an annual average (mass/year $\times 1$ year/3.15E7 second). For hourly averaging times, the emission rate should be the maximum (potential or actual) hourly average (mass/hour $\times 1$ hour/3,600 second).

- Location: For ISC3 runs, UTM coordinates should be used. These can be obtained from the previous INEEL PSD Assessmentc for existing sources, the INEEL stack emissions inventory maintained by BBWI Environmental Affairs, or the INEEL GIS database.

- $\quad$ Stack Height: Use the height (m) of the stack top above the ground (i.e., for a stack on a building, it is the building height plus the actual stack height).

- Stack Diameter: Use the inside diameter $(\mathrm{m})$ of the stack at the release point. If the stack is not round, use an equivalent diameter of a circle with the same area as the opening.

- Exit Velocity: This is the speed (m/second) of exiting stack gases. Velocity may need to be

Part B-33 
adjusted for certain types of stacks (such as horizontal or capped vents). Velocity may be calculated from stack flow rate and stack diameter. Lower values are more conservative. Actual cubic feet per minute (ACFM) flow rate $\left(V_{A}\right)$ should be used and may be calculated by:

$V_{A}=V_{S}\left(\frac{P_{S}}{P_{A}}\right)\left(\frac{T_{A}}{T_{S}}\right)$

where

$$
\begin{aligned}
& \mathrm{V}_{\mathrm{S}}=\text { standard conditions flow rate (SCFM) as measured by stack flow meter } \\
& \mathrm{P}_{\mathrm{S}}=\text { standard pressure (29.92 in. mercury) } \\
& \mathrm{P}_{\mathrm{A}}=\begin{array}{l}
\text { ambient pressure at the INEEL (25.06 in. mercury) (Clawson, Start, and } \\
\text { Ricks 1989) }
\end{array} \\
& \mathrm{T}_{\mathrm{S}}=\text { standard temperature }(\mathrm{K}) \text { as specified by flow rate manufacturer } \\
& \mathrm{T}_{\mathrm{A}}=\text { stack gas temperature }(\mathrm{K})
\end{aligned}
$$

- Exit Temperature: This is the temperature of stack gases at the stack release point. Lower values are more conservative (result in less plume rise).

- Building Dimensions: Wake effects have historically not been evaluated at the INEEL because these effects decrease as a function of distance and most source-receptor distances are large at the INEEL. However, previous modeling studies ${ }^{d}$ have shown that wake effects may need to be considered for some locations (e.g., CFA/Highway 20 or TAN/Highway 33 analyses). A conservative alternative is to assume a ground-level release, although this may result in unrealistically high model results. At the INEEL Research Complex (IRC) in Idaho Falls, building wake effects must be considered because of the short source-receptor distances.

For ISC-PRIME input, EPA's BPIP-PRIME must first be run to calculate the direction-specific building dimensions that ISC-PRIME requires.

- Cavity (SCREEN3 only): This is evaluated only for receptors located immediately around (within $50 \mathrm{~m}$ of) the building with the release.

- $\quad$ Particle Size Data (diameter, mass fraction, and density): These should be based on measurements or appropriate AP-42 data.

\subsection{Meteorological Data}

The INEEL has an excellent meteorological station network, currently comprising 12 on-Site telemetry stations with surface wind data. Data from eight stations located near major facilities, as well as from the NOAA tower in Idaho Falls, have been developed into various types of model input files (Table Part B-34 
$6)$.

When modeling cumulative impacts from sources located across the INEEL (e.g., PSD assessment), sources are grouped into modeling runs that use one of three primary met tower locations, depending on the source location (Figure 1):

- GRI for sources located in the central INEEL area (NRF, Test Reactor Area [TRA], INTEC, CFA, RWMC, Power Burst Facility [PBF], and Auxiliary Reactor Area [ARA]

- $\quad$ LOF for sources located in the northern INEEL area (Test Area North [TAN], Water Reactor Research Test Facility [WRRTF], and Loss of Fluid Test [LOFT])

- $\quad$ EBR for Argonne National Laboratory-West (ANL-W) sources.

For ISCST3 and ISCLT3, 5 years of meteorological data from the tower location closest to the source should be used. For INEEL PSD modeling, 2 years of data have been used in the past, and this length of time has been established in previous [Idaho Department of Environmental Quality (DEQ)] correspondence.e If two measurement heights are available (e.g., $10 \mathrm{~m}$ and $61 \mathrm{~m}$ at the Grid 3 tower), the one closest to the source stack height should be used.

ISCST3 requires sequential hourly meteorological data in the format specified in the user's manual (EPA 1995b). The NOAA processes the raw met data into the required 1-hour averaged variables of wind direction, speed, temperature, and stability class using methods published in On-Site Meteorological Program Guidance for Regulatory Modeling Applications (EPA 1987). Missing data are filled by either NOAA or BBWI using either interpolation for short time periods or data from a nearby station for the same time period. Wind speeds between the INEEL anemometer starting threshold speed $(0.26 \mathrm{~m} / \mathrm{second})$ and $1 \mathrm{~m} /$ second should be set to a minimum $1.0 \mathrm{~m} / \mathrm{second}$ in the meteorological file. Wind speeds less than the anemometer threshold are classified as calm and should be set to $0.0 \mathrm{~m} / \mathrm{second}$ for proper calms processing in ISCST3.

ISCLT3 requires a joint frequency data set formatted as a NOAA "STAR" (TD-9773) file. The 10-year files currently in use (Table 6) were compiled and put into the required STAR format by AG, using NOAA's annual meteorological data files. Calm hours are combined into the lowest wind speed class based on the frequency of directions for that class.

In addition to the "surface" meteorological tower data described above, ISC3 requires "upper-air" mixing height data. Although the Idaho Falls NOAA office has "sounder" instrumentation to obtain on-Site mixing heights, no reliable long-term database has been developed to date. In past modeling analyses, $800 \mathrm{~m}$ has been used as an annual average mixing height based on NOAA recommendations, ${ }^{\mathrm{f}}$ and $150 \mathrm{~m}$ has been used as a worst-case hourly value at the request of the DEQ.

Table 6. Meteorological stations on the INEEL that have model input files.

\begin{tabular}{|c|c|c|c|c|}
\hline \multirow{2}{*}{$\begin{array}{l}\text { Station } \\
\text { ID }\end{array}$} & \multirow[t]{2}{*}{ Description/Location } & \multirow{2}{*}{$\begin{array}{c}\text { Anemometer } \\
\text { Height } \\
(\mathrm{m}) \\
\end{array}$} & \multicolumn{2}{|c|}{ Model Input Files } \\
\hline & & & ISCI Tза & ISCST3b \\
\hline EBR & Argonne National Laboratory West & 10 and 80 & $1994-2003$ & $88-92$ \\
\hline CFA & Central Facilities Area & 15 & 1994-2003 & $99-01$ \\
\hline GRI & Grid $3-1.5 \mathrm{~km}$ north of INTEC & 10 and 61 & 1994-2003 & 97-01 \\
\hline IRC & Idaho Falls & 15 & 1999-2003 & $01-03$ \\
\hline
\end{tabular}

Part B-35 


\begin{tabular}{|c|c|c|c|c|}
\hline NRF & Naval Reactors Facility & 15 & $1994-2003$ & None \\
\hline $\mathrm{PBF}$ & Power Burst Facility & 15 & 1994-2003 & None \\
\hline RWM & Radioactive Waste Management Complex & 15 & $\mathrm{c}$ & $99-01^{c}$ \\
\hline LOF & Test Area North-LOFT & 10 and 45 & 1994-2003 & 94-98 \\
\hline TRA & Test Reactor Area & 15 & 1994-2003 & None \\
\hline
\end{tabular}
CFA data are substituted.

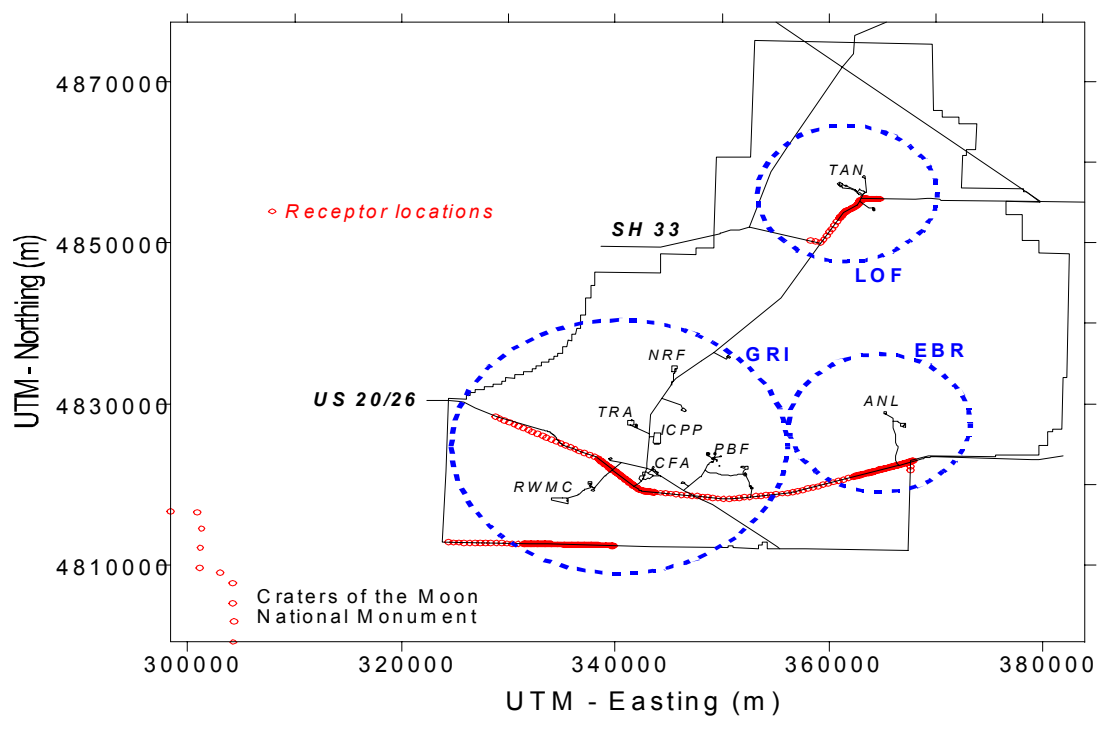

Figure 1. Source grouping (blue circles) by meteorological tower data (GRI, EBR, LOF), and discrete receptors (in red) for INEEL PSD modeling.

\subsection{Receptor Data}

Air quality criteria apply to all "ambient air" locations that could be impacted by a source. In IDAPA 58.01.01, "ambient air" is defined as "that portion of the atmosphere, external to buildings, to which the general public has access." At the INEEL, this has been interpreted to include all locations beyond the INEEL boundary (off-Site) and the three public highways that traverse the INEEL (U.S. 20/26 and State Highways 33 and 22). However, because motorists on highways that traverse the Site can be exposed to INEEL pollutants only for short periods (no residences are allowed on-Site), only pollutants with hourly averaging time criteria are assessed on the on-Site highway segments. The exception is Criteria Pollutants, for which DEQ has determined that concentrations for all averaging periods shall be calculated at the nearest ambient air location (Section 5.11, DEQ 2002). Other pollutants with annual Part B-36 
averaging time criteria (e.g., carcinogenic TAPs) are evaluated only at off-Site locations. This protocol is specified for carcinogenic TAPs in IDAPA 58.01.01.210.03.

SCREEN3 runs should evaluate discrete receptors at the minimum distance between the source (or the facility) and any applicable ambient air location (Table 7). Because of the relatively close proximity of State Highway 33 to TAN Technical Support Facility (TSF) area, tall stack releases (e.g., TAN 681-012) should be assessed at this minimum distance and greater distances to confirm that the maximum concentration from the elevated plume has been identified.

Table 7. Source locations and minimum ambient air receptor distances for selected INEEL facilities.

\begin{tabular}{|c|c|c|c|}
\hline \multirow[b]{2}{*}{ Facility Area } & \multirow[b]{2}{*}{ Source Number } & \multicolumn{2}{|c|}{ Minimum Receptor Distance $(\mathrm{m})$ and Location ${ }^{\mathrm{a}}$} \\
\hline & & Hourly Average $b$ & Annual Average ${ }^{c}$ \\
\hline ANL-W & EBR-II-705 & $5,240 \mathrm{SSE}$ & $5,240 \mathrm{SSE}$ \\
\hline CFA & CFA $^{d}$ & 1,850 U.S. 20 & $9,500 \mathrm{~S}$ \\
\hline INTEC & CPP-767 & 5,699 U.S. 20 & $13,500 \mathrm{~S}$ \\
\hline IRC & IF-603 & $82 \mathrm{~m} \mathrm{~N}$. Boulevard & $105 \mathrm{~N}$ \\
\hline NRF & $\mathrm{NRF}^{\mathrm{d}}$ & 9,986 NNW & $9,986 \mathrm{NNW}$ \\
\hline RWMC & WMF-603 & 2,918 EBR-I & $5,600 \mathrm{~S}$ \\
\hline TAN-TSF & TAN-734 & 864 State Highway 33 & $9,400 \mathrm{~N}$ \\
\hline TRA & TRA-770 & 5,504 U.S. 20 & $10,400 \mathrm{NW}$ \\
\hline $\mathrm{MWSF}^{\mathrm{e}}$ & MWSF & 4,057 U.S. 20 & $10,166 \mathrm{~S}$ \\
\hline \multicolumn{4}{|c|}{$\begin{array}{l}\text { a. Distances were taken from DOE-ID (1991) and Geographical Information System (GIS) data. Ambient air locations include } \\
\text { public access highways, the EBR-I public access site, and the INEEL Site boundary locations (given in cardinal directions from } \\
\text { a facility). } \\
\text { b. For hourly increments (e.g., 24-hour noncarcinogenic TAP AACs), both public road and Site boundary receptors were } \\
\text { evaluated. } \\
\text { c. For annual increments (e.g., carcinogenic TAPs), only Site boundary receptors are applicable. } \\
\text { d. Buildings in the area nearest to ambient receptor. } \\
\text { e. Mixed Waste Storage Facility. }\end{array}$} \\
\hline
\end{tabular}

$\underline{\text { ISC3 }}$ runs for applications other than PSD are typically made using at least two types of receptor grids to identify the location of maximum air concentration. The initial run is made with a coarse grid to determine regional dispersion trends and the general areas of maximum impact. Coarse grids typically cover a large area (e.g., 100 to $500 \mathrm{~km}^{2}$ ) and use receptor spacings of 200 to $500 \mathrm{~m}$ to keep the total number of receptors modeled at a reasonable number (to minimize computer run times). Extra receptors should be placed over elevated areas (e.g., Big Southern Butte) to ensure that any complex terrain effects are accounted for. Refined grids with receptor spacings of $100 \mathrm{~m}$ are then evaluated in the areas of maximum impact (as determined by the coarse grid results) to determine the final maximum concentration impacts. 
PSD modeling at the INEEL has been accomplished using a single discrete receptor array at highway and Site boundary locations that have shown maximum impacts from previous modeling studies (DOE-ID 1995). These locations include U.S. Highway 20/26, the southwestern INEEL boundary, and a section of State Highway 33 south of TAN (Figure 1). Receptor spacings range from 2,500 $\mathrm{m}$ in areas of low impact to $100 \mathrm{~m}$ in areas of higher impacts. This discrete grid was also used in the June 10, 1996, INEL PSD Revision 1 (see footnote b, p. B-4), but may need to be reassessed on the next PSD revision if significant new sources are evaluated.

When evaluating impacts from a new stack source, DEQ has requested that a refined grid at the Site boundary be evaluated. This grid should include Site boundary receptors and additional rows of receptors beyond the Site boundary to confirm that concentrations decrease beyond the boundary (Figure 2).

Receptor elevations must be input for ISC3 to account for any complex terrain effects. Previous modeling studies (Keck and Abbott 1997) have shown that maximum impacts from the INTEC Main Stack may occur beyond the Site boundary on the northern slopes of Big Southern Butte where the plume impacts the rising terrain. It is, therefore, recommended that future modeling of significant stack sources on the INEEL assess both a Site boundary refined grid and elevated terrain refined grids in areas of high impact (as indicated by the coarse grid model results) (Figure 2). Receptor elevations are obtained from the INEEL GIS database.

\subsection{Model Output and Processing}

Site-wide assessments such as those required in PSD and NEPA require that model output from different met area (e.g., GRI, LOF, and EBR) modeling runs be added to obtain cumulative impacts for a given receptor grid. This should be accomplished using a spreadsheet.

All refined modeling (ISC3) analyses should include isopleth plots that show the pollutant-specific dispersion trends (as determined from the coarse grid modeling) and the locations of the refined grids that were evaluated (Figure 2). Refined grid results should be presented in tables. 


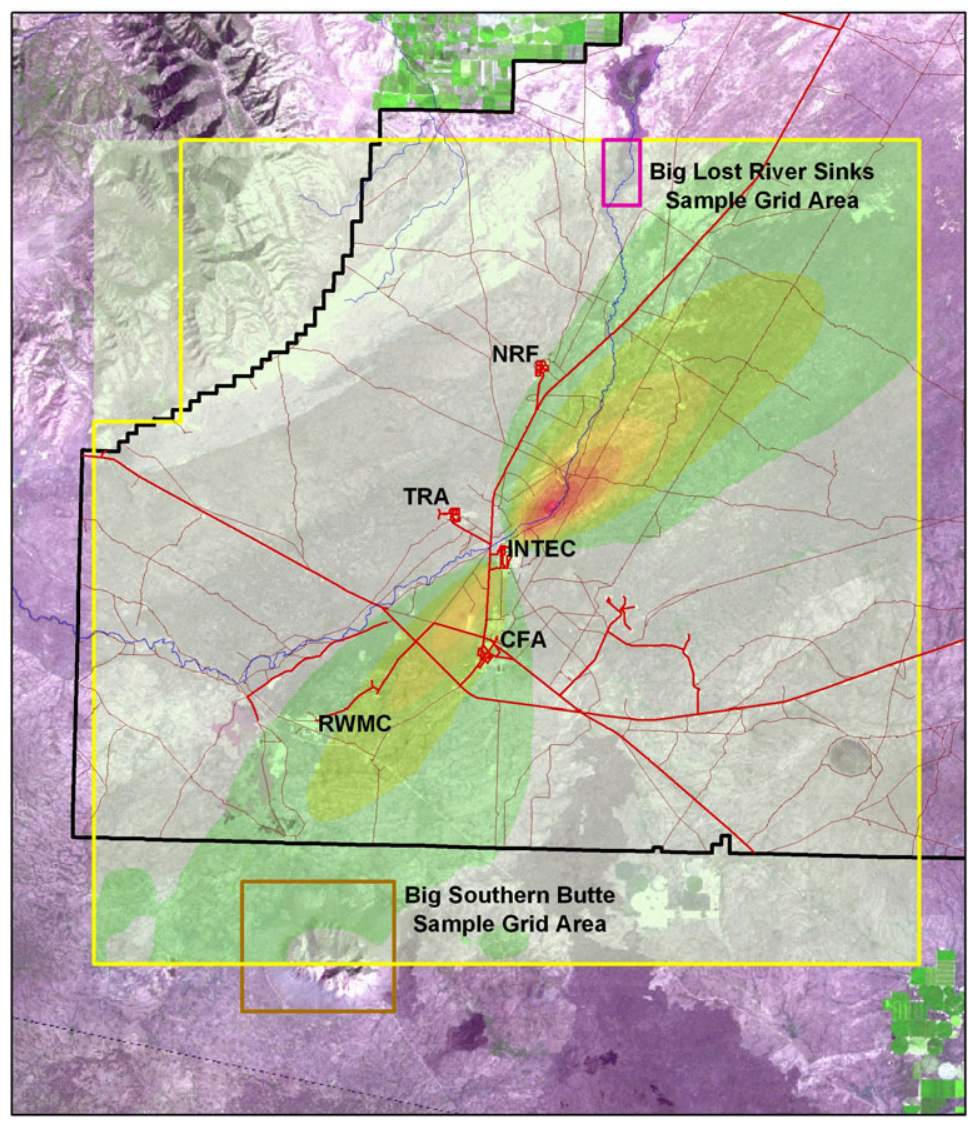

$\begin{array}{lllllllllll}0 & 1 & 2 & 3 & 4 & 5 & 6 & 7 & 8 & 9 & 10 \text { Miles }\end{array}$

$1^{N}$

Figure 2. Example of plots of isopleths from modeled INTEC Main Stack releases, and locations of refined grids (Big Lost River Sinks and Big Southern Butte). 


\section{REFERENCES}

40 CFR 51, 2003, Appendix W, "Guidelines on Air Quality Models," Code of Federal Regulations.

Clawson, K. L., G. E. Start, and N. R. Ricks, 1989, Climatography of the Idaho National Engineering Laboratory, DOE/ID-12118, 2nd ed., National Oceanic and Atmospheric Administration Air Resources Laboratory, Idaho Falls.

DEQ, 2002, State of Idaho Air Quality Modeling Guidance, Doc. ID AQ-011 (Rev. 1 12/31/02).

DOE-ID, 1995, Assessment of Prevention of Significant Deterioration Increment Consumption for Existing Sources of Emissions at the Idaho National Engineering Laboratory, DOE/ID-10508.

DOE-ID, 1991, INEL Air Permitting Handbook, DOE/ID-10324.

EPA, 1995a, SCREEN3 Model User's Guide; U.S. Environmental Protection Agency, Office of Air Quality Planning and Standards: Research Triangle Park; EPA-454/B-95-004.

EPA, 1995b, User's Guide for the Industrial Source Complex (ISC3) Dispersion Models, EPA-454/B-95-003a, U.S. Environmental Protection Agency, Office of Air Quality Planning and Standards: Research Triangle Park.

EPA, 1995c, Compilation of Air Pollutant Emission Factors, Fifth Edition, AP-42, U.S. Environmental Protection Agency, Office of Air Quality Planning and Standards: Research Triangle Park.

EPA, August 12, 1996, Requirements for Preparation, Adoption, and Submittal of Implementation Plans, republication of 40 CFR, Parts 51 and 52, Guideline on Air Quality Models, Federal Register Vol. 61, No. 156, p. 41838.

EPA, 1987, On-Site Meteorological Program Guidance for Regulatory Modeling Applications, EPA-450/4-87-013U.S. Environmental Protection Agency, Office of Air Quality Planning and Standards, Research Triangle Park.

Hanna, S. R., G. A. Briggs, and R. P. Hosker, 1982, Handbook on Atmospheric Diffusion, DOE/TIC-11223.

IDAPA 58.01.01, "Rules for the Control of Air Pollution in Idaho," Idaho Administrative Procedures Act.

Keck, K. N., and M. L. Abbott (Lockheed Martin Idaho Technologies Company), 1997, Screening Level Risk Assessment For The New Waste Calcining Facility, INEEL/EXT-97-00686, Draft Rev. 2.

Turner, D. B., 1994, Workbook of Atmospheric Dispersion Estimates, 2nd ed., Lewis Publishers, Boca Raton, Florida. 
a. Memorandum DOE-ID 11.12.92, "INEEL NESHAP Periodic Confirmatory Measurements Guidance."

b. Abbott, M. L., Lockheed Martin Idaho Technologies Company, Interdepartmental Correspondence to J. W. Gill, March 13, 1996, "Transmittal of Letter Report on Unit Release Concentrations," MLA-04-96.

c. Abbott, M. L., Lockheed Martin Idaho Technologies Company, Interdepartmental Correspondence to D. J. Wiggins, June 10, 1996, "INEL PSD Revision 1," MLA-07-96.

d. Abbott, M. L., Lockheed Martin Idaho Technologies Company, Letter to R. W. Russell, U.S. Department of Energy Idaho Operations Office, July 8, 1996, “CFA Building Downwash Study,” MLA-08-96.

e. Mitchell, J. R., Lockheed Martin Idaho Technologies Company, Letter to Marty Bauer, Idaho Division of Environmental Quality, July 9, 1996, “INEL'S PSD Modeling Protocol,” JRM-235-96.

f. Saggendorf, Jerry, National Oceanic and Atmospheric Administration, Memorandum to M. L. Abbott, Lockheed Martin Idaho Technologies Company, February 11, 1991, “Average INEL Mixing Depths.”

\section{Part B-41}

